\section{siman HORIZON}

PENDIDIKAN
JURNAL HORIZON PENDIDIKAN

Publish by: Library of STKIP PGRI Sumatera Barat

E-ISSN : 2775-5770

Vol. 1 No. 4 (November 2021) (733-747)

http://ejournal.stkip-pgri-sumbar.ac.id/index.php/horizon

\title{
ANALIS FAKTOR YANG MEMPENGARUHI EARNING MANAGEMENT \\ DI PERUSAHAAN MANUFAKTUR SEKTOR INDUSTRI BARANG KONSUMSI YANG TERDAFTAR DI BEI TAHUN 2015-2019
}

Geni Ramadhani, Citra Ramayani, Nilmadesri Rosya

Program Studi Pendidikan Ekonomi STKIP PGRI Sumatera Barat geniramadhani25@gmail.com

Submitted: 25-06-2021, Reviewed: 06-08-2021, Accepted: 21-10-2021

\begin{abstract}
This study aims to analyze: The effect of profitability, leverage, company size, managerial ownership, free cash flow on earnings management in manufacturing companies in the consumer goods industry listed on the IDX in 2015-2019. Earnings management is measured by discretionary accruals with the modified Jones model. The population in this study were all manufacturing companies in the consumer goods industry listed on the Indonesia Stock Exchange with a sample size of 13 companies. The data used in this study are data on manufacturing companies in the consumer goods industry listed on the Indonesia Stock Exchange in 2015-2019 using panel data regression. The results of this study indicate that profitability has no significant effect on earnings management. Leverage has a significant effect on earnings management. Firm size has no significant effect on earnings management. Managerial ownership has a significant effect on earnings management. Free cash flow has no significant effect on earnings management. Profitability, leverage, firm size, managerial ownership, free cash flow simultaneously have a significant effect on earnings management.
\end{abstract}

Keywords: Profitability, Leverage, Company Size, Managerial Ownership, Free Cash Flow and Earnings Management.

\section{PENDAHULUAN}

Laporan keuangan adalah sumber informasi keuangan suatu perusahaan pada suatu periode akuntansi yang dapat digunakan bagi stakeholder dalam menilai kinerja perusahaan tersebut. Tujuan pelaporan keuangan dari PSAK No.1 tahun 2013 adalah memberikan informasi mengenai posisi keuangan, kinerja keuangan, dan arus kas entitas yang bermanfaat bagi pengguna laporan keuangan dalam pembuatan keputusan ekonomi. Laporan keuangan perlu diketahui untuk melihat bagaimana keadaaan 
HORIZON

PENDIDIKAN
JURNAL HORIZON PENDIDIKAN

Publish by: Library of STKIP PGRI Sumatera Barat

E-ISSN : 2775-5770

Vol. 1 No. 4 (November 2021) (733-747)

http://ejournal.stkip-pgri-sumbar.ac.id/index.php/horizon kondisi keuangan suatu perusahaan. Awalnya laporan keuangan bagi perusahaan hanyalah sebagai alat penguji dari pekerjaan pembukuan, untuk selanjutnya laporan keuangan tidak sebagai alat penguji tetapi sebagai dasar untuk menentukan dan menilai posisi keuangan suatu perusahaan tersebut untuk mengambil keputusan. Untuk mengetahui posisi keuangan suatu perusahaan serta hasil-hasil yang telah dicapai oleh perusahaan tersebut perlu adanya laporan keuangan dari perusahaan yang bersangkutan. Manajemen laba adalah suatu kondisi dimana manajemen melakukan intervensi dalam proses penyusunan laporan keuangan bagi pihak eksternal sehingga dapat meratakan, menaikkan, dan menurunkan laba (Sulistiawan, 2011).

Teori keagenan menggambarkan bahwa manajemen laba terjadi sebagai akibat dari kepentingan ekonomis yang berbeda antara manajemen selaku agen dan pemilik entitas selaku prinsipal. Perbedaan kepentingan ekonomis ini bisa saja disebabkan atau menyebabkan asymmetry (kesenjangan informasi) antara pemegang saham (stakeholders) dan organisasi. Richardson dalam (Ujiyanto dan Pramuka, 2007).

Manajer cenderung lebih melakukan manajemen laba dengan mengendalikan transaksi aktual, yaitu transaksi yang tidak mempengaruhi aliran kas (Friendlan,1994) Sementara disisi lain, investor juga cendrung memusatkan perhatiannya pada laporan laba rugi karena investor berpendapat bahwa kestabilan laba akan berdampak pada kestabilan dividen.

Ada sepuluh cara untuk mengetahui manajemen laba, Sulistyanto (2008) mengemukakan sebagai berikut: Pertama, Manajemen tidak transparan. Kedua, Lingkungan yang tidak mendukung. Ketiga, Perubahan audit. Keempat, Konsultan hukum. Kelima, Perubahan prinsip dan estimasi. Keenam, Defisit yang cukup besar 


\section{JURNAL \\ HORIZON}

PENDIDIKAN
JURNAL HORIZON PENDIDIKAN

Publish by: Library of STKIP PGRI Sumatera Barat

E-ISSN : 2775-5770

Vol. 1 No. 4 (November 2021) (733-747)

http://ejournal.stkip-pgri-sumbar.ac.id/index.php/horizon

dalam arus kas operasi relatif

Secara konseptual wacana ini terhadap laba bersih (rugi). Ketujuh, Perbedaan yang substansial antara pertumbuhan penjualan dan penerimaan. Kedelapan, kenaikan atau penuruna laba kotor yang besar. Kesembilan, Mencatat pendapatan dari pembeli yang berisiko. Kesepuluh, Keberadaan komitmen serta kontijensi.

Pada dasarnya manajemen laba merupakan dampak dari kebebasan seseorang manajer untuk memilih dan menggunakan metode akuntansi tertentu ketika mencatat dan menyusun informasi dalam laporan keuangan. Hal ini disebabkan oleh beragam metode dan prosedur akuntansi diakui dan diterima dalam prinsip akuntansi. Meskipun metode dan prosedur akuntansi yang dipilih dan digunakan masih di ruang lengkup prinsip akuntansi maka apa yang dilakukan manajer dikatagorikan sebagai kecurangan. Upaya untuk mengurangi manajemen laba dianggap sebagai upaya untuk melakukan koreksi terhadap standar akuntansi. memang dapat menyelesaikan masalah manajemen laba walaupun tidak mudah. Alasannya, standar akuntansi bukan hukum tungal maupun dogma yang mengikat pemakainya untuk mengikuti secara penuh prinsip akuntansi pada dasarnya merupakan kumpulan dari berbagai metode dan prosedur akuntansi yang selama ini dipakai oleh perusahaan seluruh dunia. Ada beberapa sisi positif yang dapat diambil dari kontrovensi pandangan dan pemahaman terhadap manajemen laba. Secara umum kontroversi ini terjadi antara praktik dan akademisi yang pada dasarnya mempertanyakan apakah manajemen laba dapat dikatagorikan sebagai kecurangan (faund) atau tidak. Para praktik menilai manajemen laba sebagai kecurangan, sementara akademisi menilai manajemen laba tidak bisa dikatagorikan sebagai kecurangan.

Ada beberapa faktor yang dapat mempengaruhi manajemen laba suatu perusahaan seperti 


\section{JURNAL HORIZON}

PENDIDIKAN

JURNAL HORIZON PENDIDIKAN

Publish by: Library of STKIP PGRI Sumatera Barat

E-ISSN : 2775-5770

Vol. 1 No. 4 (November 2021) (733-747)

http://ejournal.stkip-pgri-sumbar.ac.id/index.php/horizon

Profitabilitas, Leverage, Ukuran

Perusahaan, Kepemilikan Manajerial dan Free Cash Flow. Secara teoretis, manajemen laba merupakan upaya manajer perusahaan untuk mengintervensi atau mempengaruhi informasi-informasi dalam laporan keuangan dengan tujuan untuk mengelabui stakeholder yang ingin mengetahui kinerja keuangan dan kondisi perusahaan (Sulistyanto, 2008).

Menurut Prasilya (2015:5) profitabilitas merupakan rasio untuk menilai kemampuan perusahaan salam mencapai keuntungan atau laba dalam suatu periode tertentu pada tingkat penjualan, aset dan modal saham tertentu. Indikator yang digunakan untuk mengetahui tingkat profitabilitas suatu perusahaan dalam penelitian adalah Return On Asset (ROA) rasio yang mengukur efektivitas pemakaian total sumber daya alam oleh perusahaan. Profitabilitas merupakan ukuran yang dijadikan oleh para investor untuk menilai sehat atau tidaknya suatu perusahaan dan juga dapat mempengaruhi dalam mengambil keputusan investasi kedepannya.

Leverage digunakan untuk mengukur kemampuan perusahaan dalam menjamin seluruh hutangnya dengan seluruh modal yang dimiliki perusahaan. Perusahaan dengan tingkat leverage yang tinggi termotivasi untuk melakukan manajemen laba agar terhindar dari pelanggaran hutang. Menurut Rusli Ritonga, \& Sari, (2015) leverage merupakan perbandingan antara total kewajiban dengan total aktiva perusahaan. Semakin tinggi nilai leverage maka resiko yang dihadapi investor akan semakin tinggi dan para investor akan meminta keuntungan yang semakin besar.

Ukuran perusahaan menggambarkan besar kecilnya suatu perusahaan yang ditunjukan oleh aset, jumlah penjualan, dan rata-rata jumlah aset.

Ukuran perusahaan merupakan sebagai upaya penilaian besar atau kecilnya sebuah perusahaan. Agung (2017) ukuran perusahaan sangat penting bagi investor dan kreditor 


\section{JURNAL \\ HORIZON}

PENDIDIKAN

JURNAL HORIZON PENDIDIKAN

Publish by: Library of STKIP PGRI Sumatera Barat

E-ISSN : 2775-5770

Vol. 1 No. 4 (November 2021) (733-747)

http://ejournal.stkip-pgri-sumbar.ac.id/index.php/horizon

karena akan berhubungan dengan resiko investasi yang dilakukan. Perusahaan dengan ukuran sedang dan besar lebih memiliki tekanan yang kuat dari pada stakeholdernya, agar kinerja perusahaan sesuai dengan harapan para investor dibandingkan dengan perusahaan kecil.

Kepemilikan manajerial merupakan kepemilikan saham oleh pihak manajemen perusahaan. Dari sudut pandang teori akuntansi, manajemen laba sangat ditentukan oleh motivasi manajer perusahaan. Dengan adanya kepemilikan manajerial maka manajer akan bertindak selaras dengan kepentingan pemegang saham sehingga dapat memperkecil prilaku oportunitis manajer. Dalam kepemilikan saham yang rendah, maka insentif terhadap terhadap kemungkinan terjadinya prilaku oportunistik manajer akan meningkat.

Free cash flow sering juga disebut dengan arus kas bebas sangat memiliki pengaruh pada perusahaan ketika free cash flow tinggi maka praktek manajemen laba akan cenderung semakin meningkat dengan cara meningkatkan laba untuk menutupi tindakan manajer yang tidak optimal dalam menggunakan kekayaan perusahaan. Menurut Brigham dan Houston dalam (Anisah, 2017) menyatakan bahwa arus kas bebas atau free cash flow yang berarti arus kas yang benar-benar tersedia untuk dibayarkan kepada seluruh investor setelah perusahaan menempatkan seluruh investasinya kepada aktiva tetap, produk-produk baru dan modal kerja yang dibutuhkan untuk mempertahankan operasi yang sedang berjalan.

\section{METODE PENELITIAN}

Jenis penelitian ini adalah penelitian asosiatif. Menurut Arikunto (2010) yaitu penelitian yang menguji ada tidaknya hubungan atau pengaruh antara suatu variabel dengan variabel lainnya. Sumber data yang digunakan dalam penelitian ini adalah data sekunder. Data yang dibutuhkan terdapat dalam laporan keuangan auditan dan anual 


\section{spant HORIZON}

PENDIDIKAN
JURNAL HORIZON PENDIDIKAN

Publish by: Library of STKIP PGRI Sumatera Barat

E-ISSN : 2775-5770

Vol. 1 No. 4 (November 2021) (733-747)

http://ejournal.stkip-pgri-sumbar.ac.id/index.php/horizon report tahun 2015-2019 perusahaan manufaktur sektor industri barang konsumsi dari Bursa Efek Indonesia (www.idx.co.id).

Populasi dalam penelitian ini adalah seluruh perusahaan manufaktur sektor industri barang konsumsi yang terdaftar dalam Bursa Efek Indonesia tahun 2015-2019. Sampel dalam penelitian ini adalah perusahaan manufaktur sektor industri barang konsumsi yang listing di BEI. Metode pengambilan sampel dalam penelitian ini menggunakan metode purposive sampling. Dan terdapat 13 perusahaan manufaktur sektor industri barang konsumsi yang menjadi sampel dalam penelitian ini.

Penelitian ini menggunakan variabel dependen manajemen laba. Manajemen laba dihitung menggunakan Discretionary Accrual model Jones yang telah dimodifikasi dengan rumus sebagai berikut :

a. Mengukur total accrual

Total Accrual $=$ Laba Bersih Setelah Pajak

b. Menghitung nilai accrual yang diestimasi dengan persamaan regresi OLS (Ordinary Least Square)

$$
\begin{aligned}
\text { TACt } / A t-1= & \alpha 1(1 / A t-1) \\
& +\alpha 2((\Delta R E V t / A t \\
& -1)+\alpha 3(\text { PPEt } / A t \\
& -1)
\end{aligned}
$$

Dimana :

$\mathrm{TAC}_{\mathrm{t}}$ : total accrual perusahaan $\mathrm{i}$ pada periode $\mathrm{t}$

$\mathrm{A}_{\mathrm{t}-1}$ : total aset untuk sampel perusahaan i pada akhit tahun t-1 $\mathrm{REV}_{\mathrm{t}}$ : perubahan pendapatan $\mathrm{REC}_{\mathrm{t}}$ : perubahan piutang perusahaan i dari tahun t-1 ke tahun $\mathrm{t}$

$\mathrm{PPE}_{\mathrm{t}}$ : aktiva tetap perusahaan $\mathrm{t}$

c. Menghitung non disretionary accruals model (DNA) adalah sebagai berikut:

$$
\begin{aligned}
N D A t=\alpha 1( & 1 / A t-1) \\
& +\alpha 2((\Delta R E V t \\
& -\Delta R E C t) / A t-1) \\
& +\alpha 3(P P E t / A t-1)
\end{aligned}
$$

d. Menghitung dusretionary accrual DACt : $(T A C t / A t-1)-N D A t$

Variabel yang digunakan dalam penelitian ini terdiri dari profitabilitas, leverage, ukuran perusahaan, kepemilikan manajerial, free cash flow. Profitabilitas adalah 


\section{JURNAL \\ HORIZON}

PENDIDIKAN

JURNAL HORIZON PENDIDIKAN

Publish by: Library of STKIP PGRI Sumatera Barat

E-ISSN : 2775-5770

Vol. 1 No. 4 (November 2021) (733-747)

http://ejournal.stkip-pgri-sumbar.ac.id/index.php/horizon

kemampuan perusahaan dalam

diukur dengan menggunakan

menghasilkan laba yang diukur

melalui rasio keuangan.

Profitabilitas diukur berdasarkan

Return On Asset (ROA) :

$$
\begin{aligned}
R O A=\frac{\text { laba bersih tahun berjalan }}{\text { Total Aktiva }} \\
\times 100
\end{aligned}
$$

\section{Leverage}

merupakan

kemampuan perusahaan dalam memenuhi liabilitynya. Leverage diukur berdasarkan debt to asset ratio (DAR) :

DAR $=\frac{\text { Total Hutang }}{\text { Total Modal }} \times 100$

Ukuran perusahaan merupakan suatu skala yang diklasifikasikan besar kecil perusahaan dengan berbagai cara anatara lain dinyatakan dalam total aset, nilai pasar saham, dan lain-lain. Dalam penelitian ini ukuran perusahaan diukur dengan menggunakan pengukuran :

$$
U P=L N(\text { Total Aset })
$$

Kepemilikan Manajerial merupakan kepemilikan saham oleh pihak manajemen perusahaan. Dalam penelitian ini kepemilikan manajerial pengukuran :

$$
K P=\frac{\text { Saham milik Manajer }}{\text { Saham Beredar }} \times 100
$$

Aliran kas bebas atau lebih sering dikenal free cash flow dapat diartikan aliran kas yang tersedia untuk dibagikan kepada para pemegang saham atau pemilik setelah perusahaan melakukan investasi pada aset tetap dan modal kerja yang diperlukan untuk kelangsungan usahanya. Rumus yang sering digunakan untuk menghitung free cash flow:

$$
F C F=\frac{A K O-A K I}{\text { Total Aktiva }}
$$

\section{HASIL DAN PEMBAHASAN}

Proses pengolahan data dilakukan dengan menggunakan bantuan eviws. Sesuai dengan metode analisis data bahwa dalam melakukan pengujian regresi dengan data panel terdapat tiga model regresi yang akan peneliti pilih. Ketiga tersebut memiliki common effect, fixed effect, random effect. Dalam pengujian Uji Prasyarat Model Regresi Panel yaitu uji chow test 


\section{Inan HORIZON}

PENDIDIKAN

JURNAL HORIZON PENDIDIKAN

Publish by: Library of STKIP PGRI Sumatera Barat

E-ISSN : 2775-5770

Vol. 1 No. 4 (November 2021) (733-747)

http://ejournal.stkip-pgri-sumbar.ac.id/index.php/horizon

(likelihood test ratio) menunjukan bahwa nilai periode $F_{\text {hitung }}$ adalah 0,38 dan nilai $\mathrm{F}_{\text {tabel }} \mathrm{df}(2,36)$ dengan tingkat signifikan 5\% sehingga nilai $\mathrm{F}_{\text {hitung }}<$ dari $\mathrm{F}_{\text {tabel }}$ maka $\mathrm{H}_{0}$ diterima, maka model yang lebih tepat digunakan adalah Common Effect Model. Akan tetap, keputusan penggunaan model ini belum merupakan hasil akhir karena masih terdapat pengujian lagi antara model fixed effect dengan random effect menggunakan Hausman Test. Pada uji hausman test menunjukan bahwa diperoleh nilai Chi-squares $\left(\mathrm{X}^{2}{ }_{\text {hitung }}\right)$ sebesar 3,31 dengan nilai Chisquares $\left(\mathrm{X}_{\text {tabel }}^{2}\right)$ sebesar 84,82 sehingga diperoleh nilai $\mathrm{X}^{2}$ hitung < $\mathrm{X}_{\text {tabel }}^{2}$ maka $\mathrm{H}_{0}$ diterima, model yang tepat adalah model random effect. Maka dari itu langkah selanjutnya yaitu melakukan uji Langrange Multiplier untuk memilih apakah model

Random effect atau common effect yang digunakan dalam mengestimasi data panel. Pada uji langrange multiplier hasil output menunjukan nilai breusch-pagan $0.15>0.05$ maka $\mathrm{H}_{0}$ diterima. Metode yang tepat digunakan adalah Common Effect Model. Karena datanya signifikan dan aman dilakukan uji lanjutan.

Tabel 1 Hasil Output Uji T Statistik

\begin{tabular}{|c|c|c|c|c|}
\hline $\begin{array}{c}\text { Variabel } \\
\text { Penelitian }\end{array}$ & t-statistik & Prob & Alpha & Kesimpulan \\
\hline Profitabilitas & -0.135 & 0.89 & 0.05 & $\begin{array}{l}\text { Tidak } \\
\text { Signifikan }\end{array}$ \\
\hline Leverage & 2.205 & 0.03 & 0.05 & Signifikan \\
\hline $\begin{array}{l}\text { Ukuran } \\
\text { perusahaan }\end{array}$ & 0.658 & 0.51 & 0.05 & $\begin{array}{l}\text { Tidak } \\
\text { Signifikan }\end{array}$ \\
\hline $\begin{array}{l}\text { Kepemilikan } \\
\text { Manajerial }\end{array}$ & -2.223 & 0.03 & 0.05 & Signifikan \\
\hline Free Cash Flow & -0.407 & 0.68 & 0.05 & $\begin{array}{l}\text { Tidak } \\
\text { Signifikan }\end{array}$ \\
\hline
\end{tabular}

Sumber: Data Olahan Peneliti, 2021.

Berdasarkan hasil uji $\mathrm{T}$ diketahi variabel profitabilitas, ukuran perusahaan dan free cash flow tidak berpengaruh signifikan terhadap manajemen laba, sedangkan leverage 


\section{गnant \\ HORIZON}

PENDIDIKAN

JURNAL HORIZON PENDIDIKAN

Publish by: Library of STKIP PGRI Sumatera Barat

E-ISSN : 2775-5770

Vol. 1 No. 4 (November 2021) (733-747)

http://ejournal.stkip-pgri-sumbar.ac.id/index.php/horizon

kepemilikan manajerial berpengaruh

signifikan terhadap manajemen laba

Tabel 2 Hasil Output Uji F Statistik

\begin{tabular}{ccccc}
\hline Keterangan & F-statistik & Prob & Alpha & Kesimpulan \\
\hline $\begin{array}{c}\text { Profitabilitas, } \\
\text { Leverage, Ukuran } \\
\text { Perusahaan, }\end{array}$ & & & & \\
$\begin{array}{c}\text { Kepemilikan } \\
\text { Manajerial, Free }\end{array}$ & 3.57 & 0.007 & 0.05 & Signifikan \\
Cash Flow & & & & \\
\hline
\end{tabular}

Sumber : Data Olahan Peneliti, 2021.

Dari tabel di atas dapat diketahui hasil $\mathrm{F}_{\text {-statistik }}$ yang diperoleh sebesar 3,57 dan $F_{\text {tabel }}$ sebesar 2,36 dengan demikian terlihat hasil yang diperoleh $\mathrm{F}_{\text {statisitik }} 3,5>\mathrm{F}_{\text {tabel }} 2,36$ maka keputusannya $\mathrm{H}_{0}$ ditolak dan $\mathrm{H}_{\mathrm{a}}$ diterima jadi variabel profitabilitas, leverage, ukuran perusahaan, kepemilikan manajerial, free cash flow secara bersama-sama berpengaruh signifikan terhadap manajemen laba pada perusahaan manufaktur sektor industri barang konsumsi periode 2015-2019.

a. Pengaruh Profitabilitas terhadap Manajemen Laba pada Perusahaan Manufaktur Sektor Industri Barang Konsumsi yang Terdaftar di Bursa Efek Indonesia Periode 2015-2019

Koefisien regresi variabel profitabilitas $\left(\mathrm{X}_{1}\right)$ bernilai -0,001245 satuan, diperoleh nilai $t_{\text {statistik }}$ sebesar $0,135458<t_{\text {tabel }}$ sebesar 1,9971 dengan probability sebesar 0,8927 . Dalam tahap pengujian digunakan tingkat kesalahaan (standar Error) sebesar $05 \%$ (0,05). Hasil yang diperoleh menunjukan bahwa nilai profitabilitas sebesar $0,8927>0,05$ maka keputusannya adalah $\mathrm{H}_{0}$ diterima $\mathrm{H}_{\mathrm{a}}$ ditolak sehingga dapat disimpulkan bahwa profitabilitas tidak berpengaruh signifikan terhadap manajemen laba pada perusahaan manufaktur sektor industri barang konsumsi periode 2015-2019.

Berdasarkan hasil yang diperoleh dapat disimpulkan bahwa semakin tinggi atau rendahnya perusahaan tidak berpengaruh terhadap manajemen laba. Hal ini disebabkan semakin tinggi profitabilitas, deviden yang 


\section{JURNAL \\ HORIZON}

PENDIDIKAN
JURNAL HORIZON PENDIDIKAN

Publish by: Library of STKIP PGRI Sumatera Barat

E-ISSN : 2775-5770

Vol. 1 No. 4 (November 2021) (733-747)

http://ejournal.stkip-pgri-sumbar.ac.id/index.php/horizon

dibagikan semakin kecil. perusahaan manufaktur sektor Profitabilitas yang semakin industri barang konsumsi yang meningkat menunjukan kinerja perusahaan yang baik dan para pemegang saham akan menerima keuntungan yang semakin meningkat. Karena manajer juga mendapatkan keuntungan sehingga dia tidak melakukan tindakan manajemen laba. Hal ini sejalan dengan penelitian yang dilakukan (Pipit, 2017).

b. Pengaruh Leverage terhadap Manajemen Laba pada Perusahaan Manufaktur Sektor Industri Barang Konsumsi yang Terdaftar di Bursa Efek Indonesia pada Tahun 2015-2019

Koefesien regresi variabel leverage $\left(\mathrm{X}_{2}\right)$ bernilai 0,261781 satuan, diperoleh nilai $t_{\text {statistik }}$ sebesar $2,2052<t_{\text {tabel }}$ sebesar 1,9971 dengan probability 0,0313. Dalam tahap pengujian digunakan tingkat kesalahan (standar error) sebesara 0,05 . Hasil menunjukan bahwa nilai leverage sebesar $0,0313<0,05$ maka keputusannya adalah $\mathrm{H}_{0}$ ditolak $\mathrm{H}_{\mathrm{a}}$ diteima sehingga dapat disimpulkan bahwa leverage berpengaruh terhadap manajemen laba pada terdaftar di bursa efek indonesia pada periode 2015-2019.

Leverage merupakan jumlah utang yang digunakan untuk membiayai atau membeli aset-aset perusahaan. Jika suatu perusahaan memiliki leverage yang tinggi, maka kemungkinan untuk melakukan manajemen laba sangat besar, dan perusahaan memiliki kewajiban yang lebih besar dalam pengungkapan terhadap public.

c. Pengaruh Ukuran Perusahaan Terhadap Manajemen Laba pada Perusahaan Manufaktur Sektor Industri Barang Konsumsi yang Terdaftar di Bursa Efek Indonesia pada Tahun 2015-2019

Koefisien regresi variabel ukuran perusahaan $\left(\mathrm{X}_{3}\right)$ bernilai 0,006504 satuan, diperoleh nilai $t_{\text {statistik }}$ sebesar $0,67>t_{\text {tabel }} 1,9917$ dengan probability 0,5130. Dalam tahap pengujian digunakan tingkat kesalahan (standar error) sebesar 0,05. Hasil yang diperoleh menunjukan bahwa nilai ukuran perusahaan sebesar $0,5130>0,05$ maka keputusannya $\mathrm{H}_{0}$ diterima $\mathrm{H}_{\mathrm{a}}$ 


\section{JURNAL \\ HORIZON}

PENDIDIKAN

JURNAL HORIZON PENDIDIKAN

Publish by: Library of STKIP PGRI Sumatera Barat

E-ISSN : 2775-5770

Vol. 1 No. 4 (November 2021) (733-747)

http://ejournal.stkip-pgri-sumbar.ac.id/index.php/horizon

ditolak sehingga dapat disimpulkan bahwa ukuran perusahaan tidak berpengaruh terhadap manajemen laba pada perusahaan sektor industri barang konsumsi yang terdaftar di BEI pada tahun 2015-2019.

Hasil penelitian ini sejalan dengan penelitian (Gunawan, Darmawan, \& Purnamawati, 2015) dan (yofi, 2018) Tidak berpengaruhnya ukuran perusahaan disebabkan oleh pengawasan yang ketat dari pemerintah, analis, dan investor yang ikut menjalankan perusahaan menyebabkan manajer tidak berani untuk melakukan praktik manajemen laba. Ketatnya pengawasan akan menghambat manajer melakukan praktik manajemen laba, karena besar kemungkinan akan diketahui oleh pemerintah, analis, dan investor sehingga hal ini dapat merusak citra dan kredibilitas manajer perusahaan tersebut

d. Pengaruh Kepemilikan Manajerial Terhadap Manajemen Laba pada Perusahaan Sektor Industri Barang Konsumsi yang Terdaftar di Bursa Efek Indonesia pada Tahun 2015-2019
Koefesien regresi variabel kepemilikan manajerial $\left(\mathrm{X}_{4}\right)$ sebesar $-0,005449$ satuan, diperoleh nilai $t_{\text {statistik }}$ sebesar 2,2233 > $t_{\text {tabel }} 1,9917$ dengan probality sebesar 0,0300 . Dalam tahap pengujian digunakan tingkat kesalahan (standar error) 0,05. Hasil yang diperoleh menunjukan bahwa nilai kepemilikan manajerial sebesar $0,0300<0,05$ maka keputusannya $\mathrm{H}_{0}$ ditolak $\mathrm{H}_{\mathrm{a}}$ diterima sehingga dapat disimpulkan bahwa kepemilikan manajerial berpengaruh terhadap manajemen laba pada perusahaan manufaktur sektor industri barang konsumsi yang terdaftar di BEI pada tahun 20152019.

Dengan adanya kepemilikan saham yang dimiliki oleh manajer maka manajer akan bertindak selaras dengan kepentingan pemegang saham sehingga dapat memperkecil perilaku oportunis manajer. Dalam kepemilikan saham yang rendah, maka insentif terhadap kemungkinan terjadinya perilaku oportunistik manajer akan meningkat. Hasil penelitian ini sejalan dengan hasil 


\section{JURNAL \\ HORIZON}

PENDIDIKAN
JURNAL HORIZON PENDIDIKAN

Publish by: Library of STKIP PGRI Sumatera Barat

E-ISSN : 2775-5770

Vol. 1 No. 4 (November 2021) (733-747)

http://ejournal.stkip-pgri-sumbar.ac.id/index.php/horizon penelitian (Sesti, 2017) kepemilikan manajerial berpengaruh dengan manajemen laba.

e. Pengaruh Free Cash Flow terhadap Manajemen Laba pada Perusahaan Manufaktur Sektor Industri Barang Konsumsi yang Terdaftar di Bursa Efek Indonesia pada Tahun 2015-2019

Koefesien regresi variabel free cash flow $\left(\mathrm{X}_{5}\right)$ bernilai $-0,24402$ satuan, diperoleh nilai $t_{\text {statistik }}$ sebesar $0,5983<t_{\text {tabel }} 1,9917$ dengan probality 0,6849 . Dalam tahap pengujian digunakan tingkat kesalahaan (standar error) sebesar 0.05. hasil yang diperoleh menunjukan bahwa nilai free cash flow $0,6849>1,9917$ maka keputusannya adalah $\mathrm{H}_{0}$ diterima $\mathrm{H}_{\mathrm{a}}$ ditolak sehingga dapat disimpulkan free cash flow tidak berpengaruh signifikan terhadap manajemen laba pada perusahaan manufakur sektor industri barang konsumsi yang terdaftar di BEI pada tahun 20152019.

Perusahaan dengan arus kas bebas yang tinggi cenderung tidak akan melakukan manajemen laba, karena meskipun tanpa adanya manajemen laba, perusahaan sudah bisa meningkatkan harga sahamnya karena investor melihat bahwa perusahaan tersebut mempunyai kelebihan kas untuk pembagian deviden. Hal ini sejalan dengan penelitian (Agustia, 2013).

f. Pengaruh Prifitabilitas, Leverage, Ukuran Perusahaan,Kepemilikan Manajerial, Free Cash Flow terhadap Manajemen Laba Pada Perusahaan Manufaktur Sektor Industri Barang Konsumsi yang Terdaftar di Bursa Efek Indonesia pada Tahun 2015-2019

Berdasarkan hipotesis yang telah dilakukan diperoleh hasil profitabilitas, leverage, ukuran perusahaan, kepemilikan manajerial, free cash flow secara bersama-sama berpengaruh signifikan terhadap manajemen laba pada perusahaan manufaktur sektor industri barang konsumsi yang terdaftar di bursa efek indonesia pada tahun 20152019. Hal ini dapat dilihat dengan perbandingan antara nilai $F_{\text {hitung }} 3,57$ dan Ftabel sebesar 2,26.

Dengan demikian terlihat hasil yang diperoleh $\mathrm{F}_{\text {statistik }}>\mathrm{F}_{\text {tabel }}$ atau 3,57 > 2,26 maka keputusannya $\mathrm{H}_{0}$ ditolak dan $\mathrm{H}_{\mathrm{a}}$ diterima. Jadi variabel 


\section{JURNAL \\ HORIZON}

PENDIDIKAN
JURNAL HORIZON PENDIDIKAN

Publish by: Library of STKIP PGRI Sumatera Barat

E-ISSN : 2775-5770

Vol. 1 No. 4 (November 2021) (733-747)

http://ejournal.stkip-pgri-sumbar.ac.id/index.php/horizon profitabilitas, leverage, ukuran perusahaan, kepemilikan manajerial, free cash flow secara bersama-sama berpengaruh terhadap manajemen laba pada perusahaan manufaktur sektor industri barang konsumsi yang terdaftar di Bursa Efek Indonesia pada tahun 2015-2019.

Berdasarkan hasil analisis koefesien determinasi diperoleh hasil nilai $R$ squared sebesar 0,144180 yang artinya 14,42 perubahan pada variabel dependen (manajemen laba) dan dapat dijelaskan oleh variabel independen (profitabilita, leverage, ukuran perusahaan, kepemilikan manajerial dan free cash flow) sedangkan sisanya $\quad 85,58 \%$ dipengaruhi oleh variabel lain yang tidak termaksud dalam penelitian ini.

\section{KESIMPULAN}

Berdasarkan hasil penelitian dan pembahasan dapat disimpulkan bahwa :

1. Profitabilitas tidak berpengaruh signifikan terhadap manajemen laba pada perusahaan manufaktur sektor industri barang konsumsi yang terdaftar di Bursa Efek
Indonesia periode 2015-2019. Sesuai dengan koefiesien regresi variabel profitabilitas bernilai $-0,001245$ satuan, diperoleh nilai $t_{\text {statistik }}$ sebesar $-0,14$ $<\mathrm{t}_{\text {tabel }}$ 1,99 dengan probability sebesar 0,89. Dalam tahap pengujian digunakan tingkat kesalahan (standar error) 0,05. Hasil yang diperoleh menunjukan bahwa nilai profitabilitas sebesar 0,89>0,05 maka keputusannya $\mathrm{H}_{0}$ diterima $\mathrm{H}_{\mathrm{a}}$ ditolak sehingga dapat disimpulkan bahwa profitabilitas tidak berpengaruh terhadap manajemen laba pada perusahaan manufaktur sekto industri barang konsumsi yang terdaftar di Bursa Efek Indonesia pada tahun 2015-2019

2. Leverage berpengaruh signifikan terhadap manajemen laba pada perusahaan manufaktur sektor industri barang konsumsi yang terdaftar di Bursa Efek Indonesia periode 2015-2019. Sesuai dengan koefesien regresi variabel leverage (X2) bernilai 0,26 satuan, diperoleh nilai $t_{\text {statisrik }}$ 


\section{JURNAL \\ HORIZON}

PENDIDIKAN

JURNAL HORIZON PENDIDIKAN

Publish by: Library of STKIP PGRI Sumatera Barat

E-ISSN : 2775-5770

Vol. 1 No. 4 (November 2021) (733-747)

http://ejournal.stkip-pgri-sumbar.ac.id/index.php/horizon

sebesar 2,21 > $t_{\text {tabel }} 1,99$ dengan probability sebesar 0,03. Dalam tahap pengujian digunakan tingkat kesalahan (standar error) 0,05. Hasil yang diperoleh menunjukan bahwa nilai leverage sebesar 0,03 $<0,05$ maka keputusannya $\mathrm{H}_{0}$ ditolak $\mathrm{Ha}$ diterima sehingga dapat disimpulkan bahwa leverage berpengaruh terhadap manajemen laba pada perusahaan manufaktur sektor industri barang konsumsi yang terdaftar di Bursa Efek Indonesia pada tahun 20152019

3. Ukuran perusahaan tidak berpengaruh signifikan terhadap manajemen laba pada perusahaan manufaktur sektor industri barang konsumsi yang terdaftar di BEI pada tahun 2015-2019. Sesuai dengan koefesien regresi variabel ukuran perusahaan (X4) 0.006504 satuan, diperoleh nilai $t_{\text {statistik }}$ sebesar $0,66<\mathrm{t}_{\text {tabel }} 1,99$ dengan probability 0,51. Dalam tahap pengujian digunakan tingkat kesalahan (standar eror) 0,05. Hasil yang diperoleh menunjukan bahwa nilai ukuran perusahaan 0,51>0,05 maka keputusannya adalah $\mathrm{H}_{0}$ diterima dan $\mathrm{H}_{\mathrm{a}}$ ditolak

4. Kepemilikan manajerial berpengaruh terhadap manajemen laba pada perusahaan manufaktur sektor industri barang konsumsi yang terdaftar di BEI pada tahun 2015-2019. Sesuai dengan koefiesien regresi variabel (X4) sebesar $\quad-0,005449$ satuan, diperoleh nilai $t_{\text {statistik }}$ sebesar $-2,22$ $<$ ttabel 1,99 dengan probability 0,03 . Dalam tahap pengujian digunakan tingkat kesalahan (standar error) sebesar 0,05. Hasil yang diperoleh $0,03<0,05$ maka keputusannya adalah $\mathrm{H}_{0}$ ditolak $\mathrm{H}_{\mathrm{a}}$ diterima.

5. Free cash flow tidak berpengaruh terhadapp manajemen laba yang terdaftar di BEI pada tahun 20152019. Sesuai dengan koefesien regresi variabel (X5) sebesar 0,024 satuan, diperoleh nilai ts $_{\text {tatistik }}$ sebesar $0,059<\mathrm{t}_{\text {tabel }} 1,99$ dengan probability 0,68. Dalam tahap pengujian digunakan tingkat kesalahan (standar error) 0,05. 


\section{samen HORIZON}

PENDIDIKAN
JURNAL HORIZON PENDIDIKAN

Publish by: Library of STKIP PGRI Sumatera Barat

E-ISSN : 2775-5770

Vol. 1 No. 4 (November 2021) (733-747)

http://ejournal.stkip-pgri-sumbar.ac.id/index.php/horizon
Hasil yang diperoleh menunjukan

bahwa nilai free cash flow $0,68>$ 0,05 maka keputusannya adalah $\mathrm{H}_{0}$ diterima $\mathrm{H}_{\mathrm{a}}$ ditolak.

6. Profitabilitas, leverage, ukuran perusahaan, kepemilikan Manajerial, free cash flow secara bersama-sama berpengaruh signifikan terhadap manajemen laba pada perusahaan manufaktur sektor industri barang konsumsi yang terdaftar di BEI pada tahun 2015-2019. Sesuai dengan hasil pengujian dapat dilihat F-statitik yang diperoleh sebesar 3,57 dan $F_{\text {tabel }}$ 2,36 dengan demikian terlihat hasil yang diperoleh $\mathrm{F}_{\text {statistik }}>\mathrm{F}_{\text {tabel }}$ maka keputusanya $\mathrm{H}_{0}$ ditolak dan $\mathrm{H}_{\mathrm{a}}$ diterima.

\section{DAFTAR PUSTAKA}

Agustia, D. (2013). No Title. Akuntansi, 4(2), 105-118.

Akuntansi, P. S., Ekonomika, F., \& Stikubank, U. (2018). Deteksi Manajemen Laba: Leverage, Free Cash Flow, Profitabilitas Dan Ukuran Perusahaan ( Studi Kasus Pada Perusahaan Manufaktur Yang Terdaftar Di Bei Periode 2013-2016 ). 978979.
Anisah, K. F. (2017). Pengaruh Free Cash Flow dan Leverage Terhadap Manajemen Laba Pada Perusahaan Manufaktur di BEI. Jurnal Akuntansi, 3(2), 64-76.

Arikunto. (2010). Prosedur Penelitian Suatu Pendekatan Praktis, Edisi Revisi 2010,Cetakan Keempatbelas. Jakarta: Rineka Cipta.

Gunawan, I. K., Darmawan, N. A. S., \& Purnamawati, I. G. A. (2015). Pengaruh Ukuran Perusahaan, Profitabilitas, dan Leverage Terhadap Manajemen Laba. Jurnal Akuntansi Program S1 Universitas Pendidikan Ganesha, $\quad$ 03(1). https://doi.org/http://dx.doi.org/ 10.23887/jimat.v3i1.5272

Sulistyanto. (2008). No Title. Jakarta: PT Gramedia Widiasarana Indonesia.

Sulistiawan. (2011). Creative Accounting (A. Sugiarto, ed.). Jakarta

Yofi. (2018). Pengaruh Leverage Terhadap Manajemen Laba Pada Perusahaan Manufaktur. 